\title{
Supply chain risk management processes for resilience: A study of South African grocery manufacturers
}

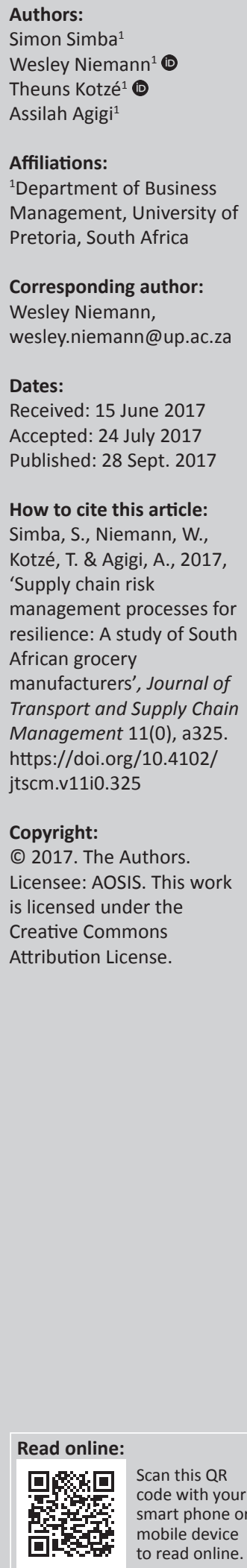

Background: The supply chain risk management (SCRM) process is aimed at the implementation of strategies that assist in managing both daily and exceptional risks facing the supply chain through continuous risk assessment to reduce vulnerability and ensure continuity.

Purpose: The purpose of the study was to determine whether the SCRM process enables supply chain resilience among grocery manufacturers in South Africa. The fast-moving consumer goods (FMCG)-manufacturing industry faces increased risk because of the nature of their products being perishable with a limited shelf life.

Method: This study was conducted using a descriptive qualitative research design. Data were collected by means of 12 semi-structured interviews with senior supply chain practitioners within the South African grocery manufacturing industry.

Findings: The study found that most firms informally implement SCRM processes of risk identification, assessment, mitigation and monitoring to mitigate disruptions. Furthermore, the findings indicate that the SCRM processes facilitate resilience among grocery manufacturers in South Africa.

Conclusion: The managerial implications show that supply chain managers of grocery manufacturers should formalise the SCRM process and develop risk assessment scales to better prioritise risks in order to run a resilient supply chain. The research contributes to the supply chain management field by adding to the scarce literature relating to SCRM as an enabler of supply chain resilience in a South African context.

\section{Introduction and problem statement}

Because of the competitive business environment today, firms have been forced to expand their operations globally for cost effectiveness (Colicchia, Dallari \& Melacini 2010:680; Diabat, Kannan \& Panikar 2011:2; Pettit, Croxton \& Fiksel 2013:46). The global dispersion of operations including suppliers, manufacturing plants, warehouses and customers has increased firm network complexity and risk vulnerability (Sachdeva, Kayis \& Dana Karningsih 2012:834; Soni \& Kodali 2013:25). This has led to increased interest in supply chain resilience and supply chain risk management (SCRM) to cope with complex supply chain risks (Leat \& Revoredo-Giha 2013:219; Scholten, Sharkey Scott \& Fynes 2014:211; Wieland \& Marcus Wallenburg 2012:888; Wilding, Colicchia \& Strozzi 2012:403). SCRM has received increased attention from researchers and practitioners because of the uncertainty and complexity facing supply chains. SCRM provides effective tools and practices which, aligned with the corporate strategy, mitigates the challenges created by uncertainty and complexity (Wieland \& Marcus Wallenburg 2012:888; Wilding et al. 2012:405).

Supply chain risks are events that negatively affect supply chain operations (Leat \& RevoredoGiha 2013:221). Managing global supply chains and meeting growing customer requirements have made firms more conscious of their vulnerability to threats affecting operational and environmental activities (Harrison et al. 2013:264; Urciuoli et al. 2014:46). Several disruptions have affected firm supply chains. Examples include Ericsson which experienced a disruption in 2000 when their only supplier of integrated circuits suffered a shutdown because of a fire by lightning. The result was that Ericsson exit the mobile-phone handset business (Chakravarty 2013:40). Another example of financial losses from such disruptions include 300 billion US dollars lost because of a Japanese earthquake and $\$ 40$ billion from the explosion of a high-tech deepwater oil well in the Gulf of Mexico (Chakravarty 2013:40-41). In order to manage these risks, many firms are building supply chain resilience capabilities. 
According to Ponomarov and Holcomb (2009:131), supply chain resilience is an adaptive capability that prepares, responds and recovers supply chains from unpredicted events, through maintaining stability of operations (Park 2011:109; Wilding et al. 2012:404). An aspect of resilience gaining attention by academics to mitigate risks is SCRM (Breuer et al. 2013:333; Leat \& Revoredo-Giha 2013:220). The tools provided by SCRM assist on-going risk assessment with the goal of decreasing vulnerability and guaranteeing continuity (Breuer et al. 2013:333; Vilko, Ritala \& Edelmann 2014:5) for firms in industries such as automotive, electronics, agriculture and fast-moving consumer goods (FMCG) (Ketkar \& Vaidya 2012:60; Leat \& Revoredo-Giha 2013:220; Li, Tan \& Hida 2011:5428).

Globalisation has increased cost pressures and customer demands pressuring FMCG firms to seek and implement efficient processes and reduce redundancies through just-intime production or decreasing the supplier base (Diehl \& Spinler 2013:311; Li et al. 2011:5417). These practices have led to risks such as non-receipt of raw materials, mismatch in quantity supplied, inventory write-off, increased cost of fuel leading to higher costs of transportation, and for grocery manufacturers specifically, constraints of holding a limited amount of safety stock because of the perishability of products as well as product contamination (Glendon \& Bird 2013:4; Kärkkäinen 2003:50; Leat \& Revoredo-Giha 2013:220). These risks, in turn, are pushing firms to seek resilience capabilities through the SCRM process (Leat \& RevoredoGiha 2013:220; Töyli, Wieland \& Marcus Wallenburg 2013:312). The supply chain process entails risk identification, risk assessment, risk mitigation and risk monitoring (Sodhi, Son \& Tang 2012:5; Xie, Tummala \& Schoenherr 2011:477).

Despite increased attention, research on supply chain resilience and SCRM has been undertaken separately, and as such there is limited scientific research in the field of supply chain resilience and SCRM, considering SCRM as an enabler of supply chain resilience (Scholten et al. 2014:211; Sodhi et al. 2012:3; Töyli et al. 2013:301). An in-depth search in the literature available in the South African context further revealed a gap in the existing body of knowledge. A study by Bredell and Walters (2007) proposed a structured and disciplined framework to integrated supply risk management. A more recent study by Agigi, Niemann and Kotzé (2016) introduced supply chain resilience in the South African context, focusing on supply chain design approaches as an enabler of supply chain resilience.

Although the SCRM process is well established in literature, and the reality of increased risks is present for most global firms, the SCRM process and the management thereof are not formally implemented in firms (The Global Supply Chain Institute 2014:2). The purpose of this study was to explore whether the SCRM process enables supply chain resilience among grocery manufacturers in South Africa.

This study is guided by the following exploratory research questions:
- What are the supply chain risks faced by South African grocery manufacturers?

- What risk identification process or processes are used by the manufacturers?

- What risk assessment methods are used by the manufacturers?

- What risk mitigation practices are implemented in case of supply chain risks?

- What risk-monitoring mechanisms are used by the manufacturers?

- How does the SCRM process mitigate the risks faced by the manufacturers and enable supply chain resilience?

Based on the numerous risks facing supply chains, SCRM is growing in importance for researchers and practitioners and in protecting firms from disruptions that cause major losses in productivity and profitability. This study, therefore, makes the following contributions. Firstly, most SCRM research is based in Europe, Asia and America. This study extends SCRM research into the African context, specifically South Africa. Secondly, literature on SCRM in the FMCG industry globally is limited. This study reduces this gap and broadens SCRM to the context of grocery manufacturers. Thirdly, the managerial implications show that supply chain managers of grocery manufacturers should formalise the SCRM process and develop risk assessment scales to better prioritise risks in order to run a resilient supply chain.

The following literature review sections detail supply chain risks, supply chain resilience, SCRM and the SCRM process. The methodology section will follow thereafter. The article concludes with the presentation of the research findings, limitations and recommendations.

\section{Literature review Supply chain risks}

In seeking cost reduction and competitiveness, firms have resorted to globalisation and outsourcing, which have led to increased connectivity and interdependency (Amoo Durowoju, Kai Chan \& Wang 2012:999; Le, et al. 2013:783). As a result, risk exposure has increased because of shorter product life cycles, higher dependency on suppliers and other external players in their supply chain. These affect supply chain performance by disrupting the smooth flow of materials and information in the supply chain in turn causing financial losses (Chakravarty 2013:39; Punniyamoorthy, Thamaraiselvan \& Manikandan 2013:80; Rajesh, Ravi \& Venkata Rao 2014:246).

According to Liu, Lin and Hayes (2010:224), risks are any exposure posing a threat to the existence of a business (Spiegler, Naim \& Wikner 2012:6162). Firm risks can be divided into four main areas, namely financial, operational, strategic and compliance risks. However, supply chain risks comprise disruptions that interfere with the consistent movement of materials, information and finances, which may negatively influence the achievement of a firm's goals, 
as well as the supply chain, with regard to cost, quality and time (Colin et al. 2011:840; Hofmann et al. 2014:162; Spiegler et al. 2012:6162). According to Wilding et al. (2012:413), supply chain risks are categorised as internal and external risks. Internal risks include forecast inaccuracy, worker accidents, distorted information, quality issues and capacity cost, while external risks include price fluctuations, plant fires, labour disputes, customs and regulations and economic downturns (Dash Wu, Olson \& Dash Wu 2010:698; Lin \& Zhou 2011:177).

Risk drivers are the sources of supply chain risks. They determine the degree of risk and have different avenues from which they arise: from internal operations, the supply chain and the external environment (Olson \& Wu 2011:402; Pfohl, Köhler \& Thomas 2010:35). The drivers from the external environment include wars and global financial crises. Drivers from internal operations include product quality capabilities and financial solvency, and supply chain drivers include globalisation and increased outsourcing (Dash Wu et al. 2010:695; Thun, Drüke \& Hoenig 2011:516).

Real-world business scenarios of risks and their effects include Toyota's recall of gas pedals (Choy et al. 2011:1004; Rotaru, Wilkin \& Ceglowski 2014:1246) and Boeing's shortage of building parts for the 787 planes because of a disruption with their Advanced Integration Technology (Saghafian \& Van Oyen 2012:834). Apple suffered a shortage of DRAM chips because of an earthquake in Taiwan leading to customer loss (Amundson et al. 2013:3944; Chakravarty 2013:39; Liu, Li \& Wu 2014:1201). A port strike that lasted 40 days in Hong Kong from April to May 2013 also disrupted the movements of goods affecting lead time of various firms whose operations passed through the port (The Global Supply Chain Institute 2014:23).

The Barloworld supply chain foresight reported that labour unrest and inefficiency of ports and harbours in South Africa are a few of the major risks faced by South African firms. Furthermore, the report stated that South African firms tend to apply reactive strategies when faced with such challenges instead of anticipating and aligning the firms' strategies to be flexible and responsive to changes occurring in the market. The lack of effective processes within firms was cited as a constraint to implementing proactive strategies to mitigate risks (Barloworld 2014:16).

Because of the above-mentioned risks and their negative effects on firm operations and performance, firms need resilience capabilities to avoid, mitigate and reduce the effects of disruptions (Johnson, Elliott \& Drake 2013:333; Urciuoli et al. 2014:57). The need for resilient firms in South Africa, especially, is evident and this research aims to address this issue by studying South African grocery manufacturers; the SCRM processes they have in place; and importantly, to determine whether the supply chain resilience capability is present as a result of these processes.

\section{Supply chain resilience}

As mentioned previously, supply chain resilience has been growing as a research focus because of its importance in preparing firms for disruptions that negatively affect their supply chain productivity, profitability and competitiveness (Töyli et al. 2013:311; Urciuoli et al. 2014:47). It is therefore necessary to discuss supply chain resilience within risk management.

Supply chain resilience is an adaptive capability that enables preparation for unexpected events, counters disruptions and returns operations to a stable state through continuity of operations at the expected level of connectedness and control over structure and function (Johnson et al. 2013:325; Ponomarov \& Holcomb 2009:131; Töyli et al. 2013:301). Resilience is not only reactive but also a proactive, structured and an incorporated consideration of proficiencies that a supply chain possesses to deal with unforeseen events (Johnson et al. 2013:333; Wilding et al. 2012:404).

Supply chain resilience consists of two main capabilities, namely flexibility and redundancy. Redundancy focuses on limiting risks and its consequences by keeping reserves such as safety stock and sourcing from multiple suppliers (Jüttner \& Maklan 2011:247; Zsidisin \& Wagner 2010:3). Flexibility ensures speedy responses to risk that may materialise. From a supply management context, firms can invest in strong buyer-supplier relationships that motivate suppliers to take extraordinary measures to mitigate risks (Mensah \& Merkuryev 2014:316; Zsidisin \& Wagner 2010:3). Thus, to increase resilience, businesses should invest in mechanisms that facilitate both flexibility and redundancy. This is because a strategy that implements only redundancy or only flexibility would increase the risk occurrence costs (Wieland 2013:660). While the two capabilities are both important, their applicability in terms of the risks differs. Redundancy is preferable for everyday risks because of high frequency of occurrence and low impact while flexibility is preferable for exceptional risks usually of low probability and high impact which require rapid response (Kumar, Himes \& Kritzer 2014:887; Wieland 2013:662). Other capabilities facilitating resilience include visibility, collaboration and velocity (Jüttner \& Maklan 2011:252). By applying these capabilities to the supply chain, risk impact is reduced. The capabilities of resilience are intertwined with those of SCRM because they mitigate risks throughout the supply chain (Leat \& RevoredoGiha 2013:229). Additionally, some research shows that SCRM is the most pronounced resilience driver because it builds coordination within relationships in the supply chain which are essential to building resilience (Breuer et al. 2013:332; Jüttner \& Maklan 2011:255; Töyli et al. 2013:312).

\section{Supply chain risk management process}

SCRM is the implementation of strategies that assist in managing both daily and exceptional risks facing the supply chain through continuous risk assessment to reduce vulnerability and ensure continuity (Breuer et al. 2013:333; 
Wieland \& Marcus Wallenburg 2012:888). The relationship of SCRM to resilience has been supported in literature. For example, risk-oriented actions such as supply chain risk effect management and supply chain risk knowledge management have been shown to have a positive impact on resilience capabilities such as flexibility, velocity, visibility and collaboration (Jüttner \& Maklan 2011:252; Töyli et al. 2013:310).

Apart from strategies that may be implemented to manage risks in the supply chain, SCRM also comprises the SCRM process. Xie et al. (2011:477) construe the SCRM process to include risk identification, risk assessment, risk mitigation and risk monitoring, as illustrated in Figure 1. These steps equip managers with strategic information to select strategies that mitigate different risks to improve overall performance of the supply chain (Chapman, Bernon \& Haggett 2011:1030; Xie et al. 2011:481). The four phases are discussed in the next sections.

\section{Risk identification}

The first critical step of the SCRM process is risk identification as it identifies vulnerabilities and the relationships between risks both internal and external to the firm (Breuer et al. 2013:335; Colin et al. 2011:839; Sachdeva et al. 2012:835; Wilding et al. 2012:413). Without identifying risks, it is challenging to develop relevant mitigation strategies with the available expertise to reduce the risk impact (Dash $\mathrm{Wu}$ et al. 2010:696; Lin \& Zhou 2011:181; Punniyamoorthy et al. 2013:80).

Risk sources can be categorised according to external and internal risks. External risks are outside the scope of control of the firm while internal risks are associated with decisions made and actions taken within the firm (Trkman \& McCormack 2009:247; Zamora, Adarme \& Palacios 2012:396). Lin and Zhou (2011:177) outlined several sources of internal risks, which include research and development risk, production risk, planning risk and information risk. External risk sources include policy risk, supply risk and delivery risk (Lockamy 2011:412). Risk identification is finalised by linking risk sources with activities they affect in the supply chain (Breuer et al. 2013:333-334; Cagliano et al. 2012:823-824).

Because of the complex nature of supply chains, certain tools and techniques to ease the risk identification process are necessary. The methods used include locating risks, assessing the possible damage to the firm as well as its partners and the impact on the supply chain altogether (Lavastre, Gunasekaran \& Spalanzani 2012:831). The failure modes and effects analysis (FMEA) encompasses these methods as it is a

\begin{tabular}{|c|c|c|}
$\begin{array}{c}\text { Risk } \\
\text { identification }\end{array}$ & $\Rightarrow \begin{array}{c}\text { Risk } \\
\text { Mitigation }\end{array}$
\end{tabular}$\Rightarrow \begin{gathered}\text { Risk } \\
\text { Monitoring }\end{gathered}$

Source: Xie, C., Tummala, R. \& Schoenherr, T., 2011, 'Assessing and managing risks using the Supply Chain Risk Management Process (SCRMP)', Supply Chain Management: An International Journal 16(6), 477. https://doi.org/10.1108/13598541111171165

FIGURE 1: The supply chain risk management process. proactive tool that compels managers to continuously evaluate processes to identify where and how they might fail as well as to evaluate the impact of different failures in order to prevent them and to rectify the processes before an adverse event occurs (Sachdeva et al. 2012:835; Sharma \& Bhat 2014:72; Xie et al. 2011:476).

After identifying risks, the likelihood and impact of these risks on the firm are determined in the risk assessment phase.

\section{Risk assessment}

Risk assessment determines the likelihood, frequency and the impact of disruptions within a range of different possible scenarios relating to disruptions (Amundson et al. 2013:3945; Bandaly et al. 2012:265). Limited resources can be effectively allocated to mitigate critical risks through risk prioritisation effected by risk assessment (Lockamy 2014:769; Punniyamoorthy et al. 2013:94; Soni \& Kodali 2013:44).

The impact of risks is determined through the effects on the performance indicators of an organisation such as profitability and productivity. Examples of the impacts of risks include poor delivery performance, low-quality products and delivery of raw materials with wrong specifications (Ghadge et al. 2013:535; Vedel \& Ellegaard 2013:512). Risk likelihood is another essential factor that determines the probability of a risk occurring. With risk impact and likelihood, firms can attach weights to each risk to determine the most detrimental ones (Kumar et al. 2014:878; Lockamy 2014:769).

It is important to consider whether a risk has a low or high probability of occurrence as well as low or high impact on the firm. Critical risks such as a vital component supplied by one supplier may need increased safety stock to mitigate the possibility of a risk, whereas an inessential component may not need a high amount of safety stock (Kumar et al. 2014:879). Therefore, each risk requires separate assessments to identify a feasible strategy to avoid failure during mitigation (Sharma \& Bhat 2014:67; Wagner \& Neshat 2012:2888). Risk assessment tools that can be employed include FMEA (Bandaly et al. 2012:253) and supply chain simulations to aid the visibility on the impact of a risk on financial, production, logistics and trade performance (Berle, Norstad \& Asbjørnslett 2013:261; Lavastre et al. 2012:831). Following risk assessment, relevant strategies need to be developed in the risk mitigation phase.

\section{Risk mitigation}

Research on the SCRM process has mostly been performed on the risk mitigation phase because these strategies determine whether a firm would be able to effectively deal with risks (Marley, Ward \& Hill 2014:143; Scholten et al. 2014:219). Risk mitigation reduces risk probability or impact or both. It is important for managers to choose an appropriate mitigation strategy for each risk (Liu et al. 2014:1203; Sodhi et al. 2012:6; Wagner \& Neshat 2012:2888).

According to Curkovic et al. (2013:21), firms have three mitigation responses for risks which may affect their 
operations. These responses are accepting, reduction or sharing the risk with other supply chain partners. Accepting includes buffers, contingency planning and secure sourcing; reduction includes increased product differentiation, use of approved suppliers and multiple sourcing; and sharing may include supplier development initiatives (Ghadge et al. 2013:535). Mitigation strategies can also be categorised as proactive or reactive. Proactive strategies reduce the likelihood of a risk that may occur in the supply chain, while reactive strategies mitigate the effect of a risk after it has occurred (Scholten et al. 2014:216; Thun et al. 2011:5514). Proactive strategies include improved tracking and tracing and selecting high-quality suppliers with high dependability. Reactive strategies include dual sourcing, multiple sourcing and safety stocks (Kumar Sharma \& Bhat 2014:1025-1027; Thun et al. 2011:5517-5518).

Before choosing a risk mitigation strategy, each risk facing the supply chain must be evaluated against the mitigation strategies available to the firm. In order to choose a relevant mitigation strategy for any risk, a cost-benefit analysis needs to be undertaken with risk appetite as a constraint (Diehl \& Spinler 2013:317; Kumar Sharma \& Bhat 2014:1032). In completing the SCRM process, firms need to follow through to risk monitoring.

\section{Risk monitoring}

According to Jüttner and Maklan (2011:253), it is imperative for firms to closely monitor the possibilities of various risk events. Firms that monitor their supply chain have improved visibility through the several nodes linking them, which positively impacts their resilience (Töyli et al. 2013:303). Risk monitoring determines the progress of mitigation actions, corrects deviations, identifies new preventative measures and predicts possible risks (Saghafian \& Van Oyen 2012:835; Xie et al. 2011:480).

Most literature on risk monitoring is focused on the suppliers' side of the supply chain. Some of the activities that firms participate in with regard to supplier monitoring include visits to supplier sites, regular assessment of suppliers' processes and supplier performance measurement systems. When participating in these activities, firms use tools and techniques such as supplier questionnaires, benchmarking, on-site capability reviews and financial risk assessment (Curkovic et al. 2013:25; Scannell, Curkovic \& Wagner 2013:372). However, firms need to consider which supply chain partners and risks require more priority with regard to risk monitoring. This is determined by identifying the partner and risk with the highest priority (Curkovic et al. 2013:25; Jung, Lim \& Oh 2011:624; Xie et al. 2011:478). According to Xie et al. (2011:481), ever-changing risks make it important for firms to continuously monitor and assess risks in order to remain resilient in a turbulent business environment (Charkhab, Eslami \& Dehnavi 2014:420; Thun et al. 2011:5514).

In summary, the above-mentioned processes namely risk identification, risk assessment, risk mitigation and risk monitoring are essential in effectively mitigating risks. Table 1 summarises the literature sources used in the discussion of the processes.

Agigi et al. (2016:2) describe SCRM as a set course of action taken by firms to identify, assess, analyse and manage risk in the firms supply chains. The probability of events is an essential determinant of strategies to be implemented within the SCRM process (Kumar et al. 2014:879). Supply

\begin{tabular}{|c|c|c|}
\hline $\begin{array}{l}\text { Supply chain } \\
\text { management } \\
\text { process }\end{array}$ & $\begin{array}{l}\text { Description of } \\
\text { process }\end{array}$ & References \\
\hline Risk identification & $\begin{array}{l}\text { It is the process by } \\
\text { which potential risk } \\
\text { sources that may } \\
\text { affect performance } \\
\text { are identified. }\end{array}$ & $\begin{array}{l}\text { Berle et al. (2013) } \\
\text { Breuer et al. (2013) } \\
\text { Cagliano et al. (2012) } \\
\text { Colin et al. (2011) } \\
\text { Dash Wu et al. (2010) } \\
\text { Fang et al. (2013) } \\
\text { Lin and Zhou (2011) } \\
\text { Lockamy (2011) } \\
\text { Punniyamoorthy et al. (2013) } \\
\text { Sachdeva et al. (2012) } \\
\text { Sharma and Bhat (2014) } \\
\text { Trkman and McCormack (2009) } \\
\text { Wilding et al. (2012) } \\
\text { Xie et al. (2011) } \\
\text { Zamora et al. (2012) }\end{array}$ \\
\hline Risk assessment & $\begin{array}{l}\text { It determines the } \\
\text { likelihood, frequency } \\
\text { and the impact of } \\
\text { disruptions within a } \\
\text { range of different } \\
\text { possible scenarios } \\
\text { related to these } \\
\text { disruptions. }\end{array}$ & $\begin{array}{l}\text { Amoo Durowoju et al. (2012) } \\
\text { Amundson et al. (2013) } \\
\text { Bandaly et al. (2012) } \\
\text { Berle et al. (2013) } \\
\text { Curkovic et al. (2013) } \\
\text { Ghadge et al. (2013) } \\
\text { Kumar et al. (2014) } \\
\text { Lockamy (2014) } \\
\text { Punniyamoorthy et al. (2013) } \\
\text { Sharma and Bhat (2014) } \\
\text { Soni and Kodali (2013) } \\
\text { Vedel and Ellegaard (2013) } \\
\text { Wagner and Neshat (2012) }\end{array}$ \\
\hline Risk mitigation & $\begin{array}{l}\text { It is the element of } \\
\text { the SCRM process } \\
\text { that reduces the } \\
\text { probability of specific } \\
\text { risks occurring or } \\
\text { their impact or both. }\end{array}$ & $\begin{array}{l}\text { Marley et al. (2014) } \\
\text { Curkovic et al. (2013) } \\
\text { Diehl and Spinler (2013) } \\
\text { Ghadge et al. (2013) } \\
\text { Kumar Sharma and Bhat (2014) } \\
\text { Liu et al. (2014) } \\
\text { Scholten et al. (2014) } \\
\text { Sodhi et al. (2012) } \\
\text { Thun et al. (2011) } \\
\text { Wagner and Neshat (2012) }\end{array}$ \\
\hline Risk monitoring & $\begin{array}{l}\text { It is the means by } \\
\text { which firms are able } \\
\text { to determine the } \\
\text { progress of their } \\
\text { mitigation actions, } \\
\text { take corrective actions } \\
\text { for any deviations } \\
\text { and also identify } \\
\text { possible new } \\
\text { preventative measures. }\end{array}$ & $\begin{array}{l}\text { Charkhab et al. (2014) } \\
\text { Curkovic et al. (2013) } \\
\text { Jung et al. (2011) } \\
\text { Jüttner and Maklan (2011) } \\
\text { Saghafian and Van Oyen (2012) } \\
\text { Scannell et al. (2013) } \\
\text { Thun et al. (2011) } \\
\text { Töyli et al. (2013) } \\
\text { Xie et al. (2011) }\end{array}$ \\
\hline
\end{tabular}

Note: Please see the full reference list of the article, Simba, S., Niemann, W., Kotzé, T. \& Agigi, A., 2017, 'Supply chain risk management processes for resilience: A study of South African grocery manufacturers', Journal of Transport and Supply Chain Management 11(0), a325. https://doi.org/10.4102/jtscm.v11io.325, for more information. 
chain resilience is concerned with proactive and adaptive capabilities aimed at assisting firms' readiness to combat unanticipated risks where probabilities cannot necessarily be determined (Agigi et al. 2016:2). This study aims to determine whether the SCRM process can enable supply chain resilience.

\section{Research method and design Research design}

A descriptive qualitative research design was adopted for the study. This research design provides rich and detailed information from the participants' perspective and experiences on the focal topic (Neergaard et al. 2009:2). The thematic analysis technique used in this research design was flexible and therefore allowed the researcher to discover new insights through the use of semi-structured interviews (Sandelowski 2000:338).

\section{Sampling}

The unit of analysis for this study was FMCG grocery manufacturers in South Africa. Homogenous sampling was used where resembling individuals and sites were selected based on their capacity to provide rich information that assisted in understanding the focus topic (Creswell 2012:206208). Supply chain executives, general managers and logistics directors were among the participants interviewed in the study. For purposes of collecting relevant information, the interviewee selection was of utmost importance. Participants had to possess strategic and operational knowledge of the firm's supply chain and willing to share openly on risk, disruption and the mitigation strategies used. This specific sampling also permitted the understanding of the FMCG grocery manufacturing industry with product categories including frozen, canned and packed foods, confectionary, beverages, hygiene and personal products. Because of the sensitive and perishable nature of these products, the industry is vulnerable to a number of disruptions.

Twelve firms participated, permitting a total of 12 face-toface semi-structured interviews. The final sample size was decided based on the guidelines by Guest, Bunce and Johnson (2006:61), stating that 6-12 interviews are satisfactory for the development of meaningful themes, valuable interpretations and the occurrence of saturation in the data, whereby no more meaningful information is drawn out of the interviews and information obtained from further interviews proves to be repetitive. Data saturation occurred on the tenth interview conducted in this study.

\section{Data collection}

Based on the literature review, a discussion guide was compiled followed by a pilot study with one industry practitioner to verify the suitability of the questions as well as the probable duration of the interviews. From the pilot study, minor changes were made to the discussion guide, allowing for the initiation of data collection. Twelve face-to- face interviews were conducted at the participants' offices. In approaching the participants, the researchers made telephone calls, which were followed by an email with the discussion guide and informed consent form attached. A convenient time and venue were arranged through email and telephone calls.

Each interview started with a brief introduction of the interviewers, the purpose of the study, clarification of confidentiality and anonymity and a request to digitally record the interview. Each interview lasted about an hour. The researchers transcribed 10 of the 12 interviews. Two remaining interviews were transcribed, proof read and certified by a transcription service because of time constraints. The researchers checked all transcriptions while listening to the digital recording and made changes where mismatches were found with the digital recordings. The participant profiles are shown in Table 2.

\section{Data analysis}

A thematic analysis was conducted to analyse the data collected in this study. Thematic analysis identifies, organises and reports patterns within data called themes. It is flexible enough to provide rich and detailed accounts of data (Braun \& Clarke 2006:79; Penney et al. 2011:3). Initial exploratory analysis was carried out by listening to the digital recordings and matching against the transcripts in order to familiarise and engage with the data and generate codes (Creswell 2012:243). Sections of the data that included applicable information were labelled to outline the meaning of the section in particular. A broad list of codes, forming patterns, was generated and an analysis was performed to select and combine related codes. Thereafter, the related codes were combined to form bigger themes, which provided deeper meaning. The final themes were determined through their applicability in answering the study's research questions (Braun \& Clarke 2012:6365).

\begin{tabular}{|c|c|c|c|c|}
\hline $\begin{array}{l}\text { Participant } \\
\text { pseudonym }\end{array}$ & Job title & $\begin{array}{c}\text { Firm } \\
\text { pseudonym }\end{array}$ & $\begin{array}{c}\text { Product } \\
\text { category } \\
\text { pseudonym }\end{array}$ & $\begin{array}{l}\text { Interview } \\
\text { duration } \\
\text { (min) }\end{array}$ \\
\hline P1 & Planning Manager & $\mathrm{C} 1$ & $\mathrm{XY1}$ & 69 \\
\hline P2 & Supply Chain Executive & $\mathrm{C} 2$ & $\mathrm{XY} 2$ & 97 \\
\hline P3 & $\begin{array}{l}\text { Customer Service and } \\
\text { Logistics Director }\end{array}$ & C3 & $\mathrm{XY3}$ & 66 \\
\hline P4 & General Manager & $\mathrm{C} 4$ & $\mathrm{XY4}$ & 70 \\
\hline $\mathrm{P} 5 \mathrm{a}$ and $\mathrm{P} 5 \mathrm{~b}$ & $\begin{array}{l}\text { Supply Chain } \\
\text { Development Manager }\end{array}$ & C5 & XY5 & 86 \\
\hline P6 & $\begin{array}{l}\text { Supply Chain Planning } \\
\text { and Integrated Business } \\
\text { Planning Manager }\end{array}$ & C6 & XY6 & 59 \\
\hline P7 & Head of Supply Chain & $\mathrm{C7}$ & $\mathrm{XY7}$ & 57 \\
\hline P8 & $\begin{array}{l}\text { International Supply } \\
\text { Chain Manager }\end{array}$ & C8 & XY8 & 51 \\
\hline P9 & Plant Manager & C9 & XY9 & 64 \\
\hline P10 & Supply Chain Manager & C10 & $\mathrm{XY10}$ & 55 \\
\hline P11 & $\begin{array}{l}\text { Integrated Business } \\
\text { Planning Lead }\end{array}$ & C11 & $\mathrm{XY11}$ & 64 \\
\hline P12 & $\begin{array}{l}\text { General Manager Supply } \\
\text { Chain }\end{array}$ & $\mathrm{C} 12$ & $\mathrm{XY12}$ & 77 \\
\hline
\end{tabular}




\section{Trustworthiness}

The research reliability is supported through a detailed description of the research design to enable the replicability of the research by future researchers. A descriptive background to the study was provided, an interview discussion guide was developed and the process for data analysis was discussed. A rich, thick description of the sites and participants was provided followed by the deliberate use of verbatim quotes from the participants which added to the authenticity of this study (Polit \& Beck 2012:595). Furthermore, to ensure credibility, peer debriefing sessions were held with detached individuals at the researcher's university. The study was scrutinised by an experienced supply chain academic and a research methodology expert to eliminate any biases and preferences by the researchers. A detailed explanation of the grocery manufacturers who participated in this study was provided by clearly indicating the various product categories represented by each manufacturer. An audit trail, including the interview transcripts, recordings as well as the themes and subthemes, was kept. Furthermore, triangulation through individual interviews whereby some company documents on risk assessment were provided to supplement information gathered. Interviewing 12 participants from the 12 firms provided verification of the SCRM practices across grocery manufacturers because many of the practices were repeated in different firms.

\section{Findings}

This study set out to determine the use of the SCRM process for resilience among grocery manufacturers. The result of thematic analysis of the findings according to subthemes, themes and the participants are shown in Table 3.

The study identified the following themes which directly answered the study's research questions, namely (1) supply chain risks, (2) risk identification, (3) risk assessment, (4) risk mitigation and lastly (5) supply chain resilience. Supply chain risks were identified in the first step of the SCRM process and will be covered under risk assessment. Each main theme and sub-theme is discussed and supported by verbatim quotations from the participants.

\section{Risk identification}

Risk identification is the first essential step of the SCRM process whereby potential risks are identified and relationships established between internal and external risks (Breuer et al. 2013:335; Sachdeva et al. 2012:83). Under risk identification, two subthemes are discussed, namely risk drivers and risk identification tools. Fourteen risk drivers were identified during the study. These were divided into internal and external risk drivers. Internal risks are risks associated with decisions and actions taken from within a firm, while external risks are those that are out of the scope of control of the firm (Trkman \& McCormack 2009:247; Zamora et al. 2012:396). Typically, firms employ different methods to identify risks and these are discussed next.

Most of the firms investigated lacked formal risk identification tools. The tools were both reactive and proactive. Reactive methods discover risks only after they have occurred, while proactive methods discover risks before they occur (Scholten et al. 2014:216; Thun et al. 2011:5514). The reactive method to risks is illustrated by the following quotes:

Yeah so I think identifying the risks uhmm ... (Pauses) yeah reactively is always easy because it kind of hits you in the face. (P1, Male, Planning Manager)

And then you get your ad-hoc ones that just happen and then you go into a bit of a crisis management. (P3, Male, Customer Service and Logistics Director)

Proactive methods consist of FMEA, feedback, audits, brainstorming and observations. Feedback, for example, is illustrated in this quote:

So we get you know continuous feedback. We try and develop sort of contingency plans ahead of time and we expect our suppliers to do the same. (P6, Male, Integrated Business Planning Manager)

TABLE 3: Summary of themes and subthemes identified per participant.

\begin{tabular}{|c|c|c|c|c|c|c|c|c|c|c|c|c|c|}
\hline \multirow[t]{2}{*}{ Themes } & \multirow[t]{2}{*}{ Subthemes } & \multicolumn{12}{|c|}{ Firms } \\
\hline & & P1 & $\mathbf{P 2}$ & P3 & P4 & P5 & P6 & P7 & P8 & P9 & P10 & P11 & P12 \\
\hline \multirow[t]{6}{*}{ Supply chain risks } & Transportation risk & - & - & - & $x$ & - & - & $x$ & $\mathrm{x}$ & - & - & - & - \\
\hline & Supplier risk & $x$ & $x$ & $x$ & $x$ & $x$ & $x$ & $x$ & $\mathrm{x}$ & $x$ & - & $x$ & $x$ \\
\hline & Labour risk & $x$ & $x$ & $x$ & $x$ & $x$ & $x$ & $x$ & $\mathrm{x}$ & $x$ & $x$ & $x$ & $x$ \\
\hline & Forecasting risk & $x$ & $\mathrm{x}$ & - & $x$ & $x$ & - & - & $x$ & - & - & $x$ & - \\
\hline & Facility risk & - & $x$ & $x$ & $x$ & $x$ & $x$ & - & - & - & - & - & $x$ \\
\hline & Product risk & - & $x$ & $x$ & - & $x$ & $x$ & $x$ & $\mathrm{x}$ & - & - & - & $x$ \\
\hline \multirow[t]{2}{*}{ Risk identification } & Risk drivers & $x$ & $x$ & $x$ & $x$ & $x$ & $x$ & $x$ & $\mathrm{x}$ & $x$ & $x$ & $x$ & $x$ \\
\hline & $\begin{array}{l}\text { Risk identification } \\
\text { methods }\end{array}$ & $x$ & $x$ & $x$ & $x$ & $x$ & $x$ & $x$ & $x$ & $x$ & $x$ & $x$ & $x$ \\
\hline \multirow[t]{2}{*}{ Risk assessment } & Assessment tools & $x$ & $x$ & $x$ & $x$ & $x$ & $x$ & $x$ & $\mathrm{x}$ & $x$ & $x$ & $x$ & $x$ \\
\hline & Assessment scales & $x$ & $x$ & $x$ & $x$ & $x$ & $x$ & & $\mathrm{x}$ & $x$ & & & $x$ \\
\hline \multirow[t]{3}{*}{ Risk mitigation } & Flexible strategies & $x$ & $x$ & $x$ & $x$ & $x$ & $x$ & $x$ & $\mathrm{x}$ & $x$ & $x$ & $x$ & $x$ \\
\hline & Redundant strategies & $x$ & $x$ & $x$ & $x$ & $x$ & $x$ & $x$ & $\mathrm{x}$ & $x$ & $x$ & $x$ & $x$ \\
\hline & Mitigation criteria & $x$ & $\mathrm{x}$ & $x$ & $x$ & $x$ & $x$ & $x$ & $\mathrm{x}$ & $x$ & $x$ & $x$ & $x$ \\
\hline Risk monitoring & - & $x$ & $x$ & $x$ & $x$ & $x$ & $x$ & $x$ & $\mathrm{x}$ & $x$ & $x$ & $x$ & $x$ \\
\hline Supply chain resilience & - & $\mathrm{x}$ & $\mathrm{x}$ & $x$ & $\mathrm{x}$ & $\mathrm{x}$ & $\mathrm{x}$ & $\mathrm{x}$ & $\mathrm{x}$ & $\mathrm{x}$ & $\mathrm{x}$ & $x$ & - \\
\hline
\end{tabular}


In the South African context specifically, it was found that labour risks are reoccurring, and as such these risks are identified from experience. This method of risk identification was not identified in previous literature. A reason for this could be that experience as well as reoccurrence of the labour unrest risk is specific to the South African context. The quote below illustrates this point:

probably through experience have learnt what are the things that we need to watch out for so we would uhm have plans in place by our own labour unrest ... So we know once a year your wage negotiations that's a volatile period. (P3, Male, Customer Service and Logistics Director)

These methods assist grocery manufacturers in South Africa to identify potential risks for mitigation.

\section{Risk assessment}

Risk assessment assists firms to prioritise risks based on likelihood, frequency and the impact (Amundson et al. 2013:3945; Bandaly et al. 2012:265). In order to understand risk assessment, two subthemes were investigated, namely the risk assessment scales and risk assessment tools implemented by firms.

\section{Risk assessment scales}

Assessment scales assist firms to prioritise risks within their supply chain. In this study, grocery manufacturers identified two scales, namely risk likelihood and risk impact illustrated in the following quotes:

We look at the impact, the likelihood, and then the inherent risk. (P5, Male, Supply Chain Development Manager)

But if we look at our whole business as a total, we use those scales right through, right. So whether it's financial, operational, we always look at it that way to say it is at a high risk, low probability what is the financial impact of that et cetera et cetera. We use a robot system. So those little robots in all our reports say red, yellow, green to say where we think the risks would be and you know probability of them um of occurring. (P2, Male, Supply Chain Executive)

These scales are in line with literature on risk prioritisation whereby risk impact and risk likelihood are the standard risk prioritisation scales (Kumar et al. 2014:878; Lockamy 2014:769).

Two firms did not have assessment scales. This is illustrated by:

I don't think we've done, in C10, I don't think we've done an official rating scale as yet, but I think it's pretty informal in terms of the way it has been done in the past. (P10, Male, Supply Chain Manager)

The monetary fraud, those risks are generally monitored but generally in supply chain, we don't have a proper scale that we can implement. (P11, Male, Integrated Business Lead)

\section{Risk assessment tools}

The tools in the participant firms were categorised according to internal and external assessments. Internal assessments focus on the firm's operations, while external assessments focus on the external supply chain partners such as suppliers and customers. Internal assessments included Pareto analyses and Key Performance Indicators. Internal assessments are illustrated by this quote:

We have a joint scorecard so we jointly measure ourselves and the level of inventory the filling rate, on-time delivery and so on. (P7, Male, Head of Supply Chain)

External assessments included supplier audits and benchmarking. From the data, external assessments are illustrated by:

when we look at suppliers, we look at uhm together making the assessment of the risks that they have. So do they rely on just one manufacturing site, where is it located, what's the likelihood of strikes, what's the likelihood of their raw and pack material suppliers going to be disrupted and on. (P7, Male, Head of Supply Chain)

I used to be in the procurement space but yeah they do do risk assessments. So they do financial risk assessments of suppliers um and uh I think it's quite informal. (P6, Male, Integrated Business Planning Manager)

So these metrics, even within the region, they don't use proper risk assessment uh tools. They don't. You know, and I haven't been in a meeting when we have that kind ... the biggest risk that everybody talks about is CIF (Cost Insurance and Freight) risk which is financial instruments. The monetary fraud, those risks are generally monitored but generally in supply chain, we don't have a proper scale that we can implement. (P11, Male, Integrated Business Planning Lead)

As mentioned by the participants, the assessment methods used by the firms are not well established and formalised within South African grocery manufacturers. Assessment efforts and methods are implemented for financial risk but not commonly established for supply chain risks. These assessment systems do not match the assessment tools found in the literature such as FMEA (Bandaly et al. 2012:253) and simulations (Berle et al. 2013:261) for supply chain risks. Some of the participants claimed that these informal methods work for the firm, while others admitted that formal methods of assessment should be implemented for managing supply chain risks. These results are in line with the industry report compiled by the Global Supply Chain Institute, of the University of Tennessee (The Global Supply Chain Institute 2014:2).

\section{Risk mitigation}

Risk mitigation centres on formulating strategies that reduce the risk impact and likelihood or both (Liu et al. 2014:1203; Sodhi et al. 2012:6; Wagner \& Neshat 2012:2888). These strategies are categorised according to redundant and flexible strategies which are appropriate for different types of risks (Kumar et al. 2014:887; Wieland 2013:662).

Redundant strategies identified included safety stock, strategic stock and centralisation. Examples of safety stock and strategic stock are illustrated respectively: 
Yes. So example, the potential Transporter's strike that's happening now in August, we would definitely increase our stock levels in case it was going to be a full-blown strike that we couldn't service retail. (P8, Male, International Supply Chain Manager)

In times we know there's gonna be an event like strikes and stuff we will then preposition stock to then just lift the whole supply chain. We can't keep it at one site so we've got a few key 3PL warehousing companies that helps us with flex. But obviously, you speak to your customer's right? Again, you preload them as well. (P2, Male, Supply Chain Executive)

The second sub-theme of flexibility strategies is discussed in the following section.

The most frequently mentioned flexibility strategies were multi-sourcing and flexible distribution. These can be shown respectively in these participant quotes:

... we are always make sure that we have more than one supplier for a specific good or service ... and it's normally up to three suppliers. (P12, Male, General Manager: Supply Chain)

So when we enter the contract with the 3PLs, within the 3PL contract we've got various models. So you move from a fixed dedicated fleet that is yours full-time that's operated by a third party into a model where you only make use of a broker from external. So again it gives you flexibility as well. So if broker A can't help you, you've got broker B, C, D, E, F on the books. (P3, Male, General Manager)

The use of flexibility and redundant mitigation strategies in reducing the impact and likelihood of risks faced in firm's operations is supported in literature (Kumar et al. 2014:887; Wieland 2013:662).

One firm lacked multi-sourcing strategies, which increased their vulnerability shown by:

Yeah you have supplier risks in terms of so the biggest issue that we have is um kind of all our eggs are in one basket if you get where I'm coming from. We haven't got a broad base of suppliers. So the risk is that the supplier can literally do with us what he wants to when he wants to. That's the biggest risk right. (P11, Male, Integrated Business Planning Lead)

In the process of selecting mitigation strategies, there are some criteria on which strategies are assessed to find the most appropriate strategy for the risk at hand (Diehl \& Spinler 2013:317; Kumar Sharma \& Bhat 2014:1032). Some of the criteria mentioned by the participants included cost, risk and customer service. Cost and customer service were the often repeated factors to consider when selecting a mitigation strategy. Cost and customer service are supported by these statements respectively:

So it really boils down to the bottom line effect to the business and it's a financial decision at the end of the day. (P6, Male, Integrated Business Planning Manager)

The potential cost of lost sales, should the risk materialise versus the cost of holding that additional stock, yeah those, that's the simple calculation. (P10, Male, Supply Chain Manager)
These criteria are representative of the cost-benefit analysis shown by the literature as factors to consider when selecting a mitigation strategy (Diehl \& Spinler 2013:317; Kumar Sharma \& Bhat 2014:1032).

\section{Risk monitoring}

Risk monitoring is the final process of the SCRM process. Risk monitoring assesses the effectiveness of mitigation strategies, seeks to correct deviations and discovers new strategies that mitigate risks (Saghafian \& Van Oyen 2012:835; Xie et al. 2011:480). Three themes were observed and are discussed in the following sections.

In the study, some of the tools mentioned included benchmarking, supplier site reviews and market analysis. These assisted them to monitor risks both within and outside their operations. The main focus of risk-monitoring activities was suppliers, although some firms identified monitoring activities that they carried out on their retailers. The use of assessment tools is highlighted below:

The other way we find out is that we oversee on a regular basis from time to time do benchmarking exercises so we go out there and do not benchmarking but we also do market analysis, try to figure out what's going on out there in the market and bottom end, what is going to happen to it in the next couple of years and so forth you know. So and those factors tell us what's going on in the market. (P12, Male, General Manager: Supply chain)

Therefore, some of the tools identified in this study are similar to those identified in literature (Curkovic et al. 2013:25; Scannell et al. 2013:372).

Firms perform monitoring activities on their partners and risks on a daily, weekly, monthly, quarterly and annual basis depending on the risk type. The participants' statements showing their risk-monitoring activities in their operations and their partners are:

And those operational risks, there are some that we look at on a weekly basis, some we look at on a daily basis. (P9, Male, Plant Manager)

Well, again I don't think we do a risk monitoring. But you say like a price increase or a promotion that's likely to happen, it's more that we sit together, we have like a, depends on what criteria you look. We have a 3-year outlook or 1-year or 3-months or a few weeks outlook. (P7, Male, Head of Supply Chain)

Grocery manufacturers in this study prioritise their monitoring activities of risks and their partners as discussed in the literature (Curkovic et al. 2013:25; Jung et al. 2011:624), based on the criticality of the suppliers. The monitoring process identifies new risks within the firm and its partners. This follows the literature on the role of the risk-monitoring process in identifying new risks (Saghafian \& Van Oyen 2012:835; Xie et al. 2011:480).

Only one firm differed. They monitored their less reliable suppliers supported by this statement: 
And then we've got some farmers who's not as consistent, you would not, you'd probably pay more attention to them to be honest. You know you'd get the extension officers to spend more time with these farmers to make sure that they are doing the stuff right and their pivot hasn't maybe fallen over or the pump broke and they can't irrigate. So they might be more factors. (P6, Male, Integrated Business Planning Manager)

This is something to consider for several firms because programmes that increase the reliability of non-critical suppliers could be a benefit to the firm in cases where their more reliable suppliers may face a disruption.

\section{Supply chain resilience}

Supply chain resilience describes the capability of a firm to recover from a disruption back to its normal or a better state of operation (Johnson et al. 2013:325; Ponomarov \& Holcomb 2009:131; Töyli et al. 2013:301). The participants showed the role of SCRM in creating resilience as follows:

I think that, or more than a hundred years that $\mathrm{C} 5$ is running, I think we have very limited, where we could say we had major impacts on the business, which we could not manage or mitigate. (P5, Male, Supply Chain Development Manager)

I know safety stock is probably our biggest our biggest that helps us recover. That that is the biggest strategy that helps us recover because that ensures continuous supply. (P11, Male, Integrated Business Lead)

The study shows that the SCRM process is a resilience capability as shown in literature (Breuer et al. 2013:332; Jüttner \& Maklan 2011:255; Töyli et al. 2013:312).

Despite the effectiveness of the SCRM processes in several firms in the study, one firm suffered a disruption where it was not able to recover back to its normal steady state. Interestingly enough, this firm did not have a formal SCRM process in place. An illustrative quote follows describing the risk assessment tools implemented followed by an incident which occurred where the firm was unable to recover:

Um right now to be honest with you when you say tools, it's very much, we have a management tool but a process that we use is excel based. So in other words, we don't go there's a system and we punch in something in the system and the system whips up something, no. (P12, Male, General Manager: Supply Chain)

There was a particular item. Now I'm not technical so in the mill, like a compressor, somebody forgot to replenish in stock into stock. The one in the mill broke down and there was nothing. A mill was not operational uh for 12 hours. That in our industry, I don't wanna say like it's a cardinal sin. It's a sin. It cannot allow that kind of thing to happen... The impact of that is remember we've got safety stock of two weeks, 12 hours. So you can say 2 weeks minus 12 hours. You can almost never recover that in our, from our perspective.... Unfortunately, we don't produce it in the quantities that we produced it before so it's much smaller quantities so yes that element is an impact our ability to supply the market this year. We just don't know by how much right now. (P12, Male, General Manager: Supply Chain)
The above example illustrates that in cases where the SCRM process was absent in a few of its steps, the firm was unable to be resilient, thus confirming that the SCRM process is indeed a capability of supply chain resilience.

\section{Ethical considerations}

Each participant was required to read and sign an informed consent form before being interviewed. The consent form explained the study's purpose and emphasised that participation was voluntary and that the participant could withdraw at any time. The informed consent form also provided anonymity and confidentiality assurance. Before each interview, the same information was verbally summarised to the participants. Pseudonyms shown in Table 2 were used to protect the identity of the participants, product categories and firms. A research ethics committee at a South African university approved the study prior to conducting fieldwork.

\section{Discussion}

\section{Outline of the results and theoretical implications}

The purpose of this research was to determine whether the SCRM process enables supply chain resilience within grocery manufacturers. By firstly identifying the risks faced by each grocery manufacturer, the study reveals three main risks, namely labour unrest, volatile demand and supplier risks. These risks were categorised by their frequency of occurrence and impact on the firm. It was discovered that the SCRM process elements of risk identification, risk assessment, risk mitigation and risk monitoring were present within the grocery manufacturing firms. Some risk identification methods used were feedback from customers, experience and brainstorming. Risk assessment tools included internal assessments such as joint scorecards, and external assessments included benchmarking. However, some of the firms lacked formal risk assessment tools, which is a crucial step of the SCRM process as this is the stage where risks are unidentified and the next steps are planned out. Moreover, it was discovered that supply chain risks specifically lacked attention from the firms' executives. Priority is given to financial risks whereby formal procedures are in place.

The two main scales most often used for assessment were the likelihood of occurrence and impact of the risk. Mitigation strategies were several, and both redundant and flexible strategies were implemented by many grocery manufacturers, which are aligned with strategies for supply chain resilience. This is supported by previous literature showing that both types of mitigation are necessary for versatile risk mitigation (Kumar et al. 2014:887; Wieland 2013:662). Lastly, risk-monitoring methods identified included benchmarking and supplier reviews. These are acceptable as they directly relate to the main risks faced by the industry. Monitoring activities were carried out during different schedules such as daily, weekly, quarterly and annually, depending on the type of risk. 
From the above process elements, the SCRM process and its role in facilitating resilience was shown, supported by literature from other countries (Breuer et al. 2013:333; Leat \& Revoredo-Giha 2013:220). This study provides evidence for the existence of the SCRM processes of risk identification, risk assessment, risk mitigation and risk monitoring within grocery manufacturers, and it shows that aspects covered by the SCRM process are in fact in line with strategies that facilitate resilience among grocery manufacturers in South Africa. In so doing, the study adds to the scope of studies in supply chain management with regard to the SCRM process and resilience.

\section{Practical implications}

While most of the firms in the study implemented several SCRM processes, a few lacked formal assessment scales. Assessment scales are crucial because they prioritise risks. This, in turn, allows effective allocation of resources to mitigate the highest impact risks and prevents waste of resources on low impact, low likelihood risks. Therefore, it is imperative for firms especially those in the FMCG industry focusing on cost effectiveness to have proper risk assessment scales. Secondly, a structured approach to SCRM process is not in place at the firms although they use the process elements. A structured approach would benefit firms in the following ways; managers would have a similar basis of discussion and cooperate on risk mitigation. Thirdly, it would create a boundary between SCRM and other supply chain operations, which would assist in managing risks more effectively because there would be a focus division for risks. Fourthly, some firms could look at allocating a division specifically responsible for the SCRM process. This would create uniformity in dealing with disruptions. Lastly, supplier monitoring was most prevalent while their customers, retailers in this case, received less attention. Firms could increase their retailer monitoring through collaboration with retailers. This would, in turn, reduce some risks especially with regard to forecasting and would drive a resilient supply chain altogether.

\section{Limitations and future research}

The focus of this study was limited to FMCG grocery manufacturers. However, this provides several opportunities for future research, especially in other risk-prone contexts. Different manufacturers of consumer goods may be researched such as electronics and clothing or different industry contexts such as the automotive industry. Furthermore, the study could be replicated to include other tiers of the FMCG grocery industry, such as wholesalers and grocery retailers in order to paint a clearer picture of the SCRM processes for resilience. Because the research was based in South Africa, it would be interesting to see whether similar results would be obtained if the study were to be replicated in other countries in Africa with similar economies such as Kenya, Nigeria and Angola.

\section{Conclusion}

The main objective of the research undertaken was to provide insight into the SCRM process implementation within South African FMCG grocery manufacturers as well as to identify whether the SCRM process enables supply chain resilience. The study was executed using a descriptive qualitative research design through 12 semi-structured interviews conducted with supply chain practitioners within the South African grocery manufacturing industry. It was discovered that several methods for risk identification were used such as brainstorming and audits. Risk assessment included internal and external assessments with risk impact and likelihood as assessment scales. Risk mitigation methods of flexibility such as multi-sourcing and flexible distribution and redundant strategies such as safety stock and mapping; lastly, with the investigation of risk monitoring, supplier-monitoring prioritisation was identified along with risk-monitoring tools such as Key Performance Indicators.

Furthermore, the implementation of the SCRM process showed increased resilience among grocery manufacturers when faced with a disruption. Despite the success of the SCRM process in facilitating resilience, some firms revealed that the SCRM process as a whole has not received much attention as a formal process; instead, some elements of the process are used in isolation. One firm, in particular, especially lacked a formal SCRM process and was unable to recover from a disruption despite having some of the process elements in place. Risk assessment tools, specifically, were absent from the SCRM process. This implies that in some cases, firms are unable to avoid or mitigate risks despite having some systems in place to prevent them. Through processes such as SCRM, the firms can reduce the effects of these risks. Therefore, firms are encouraged to implement the SCRM process as a formal process as well as a supply chain resilience enabler because it reduces risk impact and likelihood which prevents loss of productivity and profitability as a result of disruptions.

\section{Acknowledgements Competing interests}

The authors declare that they have no financial or personal relationships that may have inappropriately influenced them in writing this article.

\section{Authors' contributions}

This article is based on the MPhil dissertation of S.S. who was the main researcher. W.N. assisted as a supervisor with the conceptualisation, literature review, research instrument and review of the draft manuscript. T.K. provided methodological and technical guidance. A.A. made content revisions and additions. 


\section{References}

Agigi, A., Niemann, W. \& Kotzé, T., 2016, 'Supply chain design approaches for supply chain resilience: A qualitative study of South African fast-moving consumer goods grocery manufacturers', Journal of Transport and Supply Chain Management 10(1), 15. https://doi.org/10.4102/jtscm.v10i1.253

Amoo Durowoju, O., Kai Chan, H. \& Wang, X., 2012, 'Entropy assessment of supply chain disruption', Journal of Manufacturing Technology Management 23(8), $998-$ 1014. https://doi.org/10.1108/17410381211276844

Amundson, J., Brown, A., Shuaib, M., Badurdeen, F., Jawahir, I.S., Goldsby, T. et al., 2013, 'Bayesian methodology for supply chain risk analysis: Concept and case studies', Paper presented at the 2013 Industrial and Systems Engineering Research Conference, Puerto Rico, 18-22 May, pp. 3944-3953, viewed 03 August 2015 from http://0-search.proquest.com.innopac.up.ac.za/docview/1471961627/fullt extPDF/12674B20C3FC4ADAPQ/1?accountid=14717

Bandaly, D., Satir, A., Kahyaoglu, Y. \& Shanker, L., 2012, 'Supply chain risk management -1 : Conceptualization, framework and planning process', Risk Management 14(4), 249-271. https://doi.org/10.1057/rm.2012.7

Barloworld, 2014, Supply chain foresight, viewed 16 July 2017, from http://barloworldlogistics.com/wp-content/uploads/2017/04/supplychainforesight-report-2014. pdf

Berle, Ø., Norstad, I. \& Asbjørnslett, B.E., 2013, 'Optimization, risk assessment and resilience in LNG transportation systems', Supply Chain Management: An International Journal 18(3), 253-264. https://doi.org/10.1108/SCM-03-2012-0109

Braun, V. \& Clarke, V., 2006, 'Using thematic analysis in psychology', Qualitative ResearchinPsychology3(2),77-101.https://doi.org/10.1191/1478088706qp063oa

Bredell, R. \& Walters, J., 2007, 'Integrated supply chain risk management', Journal of Transport and Supply Chain Management 1(1), 1-17. https://doi.org/10.4102/ Transport and
jtscm.v1i1.3

Breuer, C., Siestrup, G., Haasis, H.-D. \& Wildebrand, H., 2013, 'Collaborative risk management in sensitive logistics nodes', Team Performance Management: An management in sensitive logistics nodes,
International Journal 19(7/8), 331-351.

Cagliano, A.C., De Marco, A., Grimaldi, S. \& Rafele, C., 2012, 'An integrated approach to supply chain risk analysis', Journal of Risk Research 15(7), 817-840. https://doi. org/10.1080/13669877.2012.666757

Chakravarty, V., 2013, 'Managing a supply chain's web of risk', Strategy \& Leadership 41(2), 39-45. https://doi.org/10.1108/10878571311318231

Chapman, P., Bernon, M. \& Haggett, P., 2011, 'Applying selected quality management techniques to diagnose delivery time variability', International Journal of Quality \& Reliability Management 28(9), 1019-1040. https://doi.org/10.1108/02656 711111172568

Charkhab, H.K., Eslami, S.R. \& Dehnavi, H.D., 2014, 'Linking risk management practices and strategies to performance: Case study: Ceramic and tiles industry", International Journal of Academic Research in Accounting, Finance and Management Sciences 4(2), 417-428.

Choy, K.L., Kei Tse, Y., Hua Tan, K., Ho Chung, S. \& Kim Lim, M., 2011, 'Quality risk in global supply network', Journal of Manufacturing Technology Management 22(8), 1002-1013. https://doi.org/10.1108/17410381111177458

Colicchia, C., Dallari, F. \& Melacini, M., 2010, 'Increasing supply chain resilience in a global sourcing context', Production Planning \& Control 21(7), 680-694. https:// doi.org/10.1080/09537280903551969

Colin, J., Pfohl, H.C., Gallus, P. \& Thomas, D., 2011, 'Interpretive structural modeling of supply chain risks', International Journal of Physical Distribution \& Logistics Management 41(9), 839-859. https://doi.org/10.1108/09600031111175816

Creswell, J.W., 2012, Education research: Planning, conducting and evaluating quantitative and qualitative research, 4 th edn., Pearson, Boston, MA.

Curkovic, S., Scannell, T., Wagner, B. \& Vitek, M., 2013, 'Supply chain risk management within the context of COSO's enterprise risk management framework', Journal of
Business Administration Research 2(1), 15-28. https://doi.org/10.5430/jbar. v2n1p15

Dash Wu, D., Olson, D.L. \& Dash Wu, D., 2010, 'A review of enterprise risk management in supply chain', Kybernetes 39(5), 694-706. https://doi.org/10.1108/03684 in supply chain

Diabat, A., Kannan, G. \& Panikar, V., 2011, 'Supply chain risk management and its mitigation in a food industry', International Journal of Production Research 50(11), mitigation.

Diehl, D. \& Spinler, S., 2013, 'Defining a common ground for supply chain risk management - A case study in the fast-moving consumer goods industry', International Journal of Logistics Research and Applications 16(4), 311-327. International Journal of Logistics Research and
https://doi.org/10.1080/13675567.2013.813443

Fang, J., Zhao, L., Fransoo, J.C. \& Van Woensel, T., 2013, 'Sourcing strategies in supply risk management: An approximate dynamic programming approach', Computers \& Operations Research 40(5), 1371-1382. https://doi.org/10.1016/j.cor.2012.08.016

Ghadge, A., Dani, S., Chester, M. \& Kalawsky, R., 2013, 'A systems approach for modelling supply chain risks', Supply Chain Management: An International Journal 18(5), 523-538. https://doi.org/10.1108/SCM-11-2012-0366

Glendon, L. \& Bird, L., 2013, 5th Annual Survey Supply Chain Resilience 2013, Business Continuity Institute, viewed 21 April 2015, from https://www.zurich.com/ media/.../supply-chain-resilience-2013.pdf?la

Guest, G., Bunce, A. \& Johnson, A., 2006, 'How many interviews are enough?: An experiment with data saturation and variability', Field Methods 18(1), 59-82. https://doi.org/10.1177/1525822X05279903
Harrison, T.P., Houm, P.J., Thomas, P.J. \& Craighead, C.W., 2013, 'Supply chain disruptions are inevitable - get READI: Resiliency enhancement analysis via disruptions are inevitable - get READI: Resiliency enhancement analysis via
deletion and insertion', Transportation Journal 52(2), 264-276. https://doi. deletion and insertion', Transportation
org/10.5325/transportationj.52.2.0264

Hofmann, H., Busse, C., Bode, C. \& Henke, M., 2014, 'Sustainability-related supply chain risks: Conceptualization and management', Business Strategy and the Environment 23(3), 160-172. https://doi.org/10.1002/bse.1778

Johnson, N., Elliott, D. \& Drake, P., 2013, 'Exploring the role of social capital in facilitating supply chain resilience', Supply Chain Management: An International Journal 18(3), 324-336. https://doi.org/10.1108/SCM-06-2012-0203

Jung, K., Lim, Y. \& Oh, J., 2011, 'A model for measuring supplier risk: Do operational capability indicators enhance the prediction accuracy of supplier risk?', British Journal of Management 22(4), 609-627. https://doi.org/10.1111/j.1467-8551. 2010.00697.x

Jüttner, U. \& Maklan, S., 2011, 'Supply chain resilience in the global financial crisis: An emprical study', Supply Chain Management: An International Journal 16(4), 246259. https://doi.org/10.1108/13598541111139062

Kärkkäinen, M., 2003, 'Increasing efficiency in the supply chain for short shelf life goods using RFID tagging', International Journal of Retail \& Distribution Management 31(10), 529-536. https://doi.org/10.1108/09590550310497058

Ketkar, M. \& Vaidya, O.S., 2012, 'Study of emerging Issues in supply risk management in India', Procedia - Social and Behavioral Sciences 37, 57-66. https://doi org/10.1016/j.sbspro.2012.03.275

Kumar, S., Himes, K. \& Kritzer, C., 2014, 'Risk assessment and operational approaches to managing risk in global supply chains', Journal of Manufacturing Technology Management 25(6), 873-890. https://doi.org/10.1108/JMTM-04-2012-0044

Kumar Sharma, S. \& Bhat, A., 2014, 'Supply chain risk management dimensions in Indian automobile industry', Benchmarking: An International Journal 21(6), 10231040. https://doi.org/10.1108/BIJ-02-2013-0023

Lavastre, O., Gunasekaran, A. \& Spalanzani, A., 2012, Supply chain risk management in French companies', Decision Support Systems 52(4), 828-838. https://doi. org/10.1016/j.dss.2011.11.017

Le, H.Q., Arch-int, S., Nguyen, H.X. \& Arch-int, N., 2013, 'Association rule hiding in risk management for retail supply chain collaboration', Computers in Industry 64(7), 776-784. https://doi.org/10.1016/j.compind.2013.04.011

Leat, P. \& Revoredo-Giha, C., 2013, 'Risk and resilience in agri-food supply chains: The case of the ASDA PorkLink supply chain in Scotland', Supply Chain Management: An International Journal 18(2), 219-231. https://doi.org/10.1108/1359854131 An Intern
1318845

Li, H.-H.J.K., Tan, K.H. \& Hida, A., 2011, 'Sustaining growth in electronic manufacturing sector: Lessons from Japanese mid-size EMS providers', International Journal of Production Research 49(18), 5415-5430. https://doi.org/10.1080/00207543.201 1.563897

Lin, Y. \& Zhou, L., 2011, 'The impacts of product design changes on supply chain risk: A case study', International Journal of Physical Distribution \& Logistics Management 41(2), 162-186. https://doi.org/10.1108/09600031111118549

Liu, L., Li, S. \& Wu, Y., 2014, 'Supply chain risk management in Chinese chemical industry based on Stochastic Chance-Constrained Programming Model', Applied Mathematics \& Information Sciences 8(3), 1201-1206. https://doi.org/10.12785/ amis/080333

Liu, S., Lin, J. \& Hayes, K.A., 2010, 'An agile and diversified supply chain: Reducing operational risks', Competitiveness Review 20(3), 222-234. https://doi. org/10.1108/10595421011047415

Lockamy, A., 2011, 'Benchmarking supplier risks using Bayesian networks', Benchmarking: An International Journal 18(3), 409-427. https://doi.org/10.1108/ 1463577111113778

Lockamy, A., 2014, 'Assessing disaster risks in supply chains', Industrial Management \& Data Systems 114(5), 755-777. https://doi.org/10.1108/IMDS-11-2013-0477

Marley, K.A., Ward, P.A. \& Hill, J.A., 2014, 'Mitigating supply chain disruptions - A normal accident perspective', Supply Chain Management: An Internationa Journal 19(2), 142-152. https://doi.org/10.1108/SCM-03-2013-0083

Mensah, P. \& Merkuryev, Y., 2014, 'Developing a resilient supply chain', ProcediaSocial and behavioral sciences 110, 309-319. https://doi.org/10.1016/j.sbspro. 2013.12.875

Neergaard, M.A., Olesen, F., Andersen, R.S. \& Sondergaard, J., 2009, 'Qualitative description - The poor cousin of health research?', BioMed Central Medical Research Methodology 9(1), 52. https://doi.org/10.1186/1471-2288-9-52

Olson, D.L. \& Wu, D., 2011, 'Risk management models for supply chain: A scenario analysis of outsourcing to China', Supply Chain Management: An International Journal 16(6), 401-408. https://doi.org/10.1108/13598541111171110

Park, K., 2011, Flexible and redundant supply chain practices to build strategic supply chain, University of Toledo, Toledo.

Penney, K., Snyder, J., Crooks, V.A. \& Johnston, R., 2011, 'Risk communication and informed consent in the medical tourism industry: A thematic content analysis of Canadian broker websites', BioMed Central Medical Ethics 12(17), 1-9. https:// doi.org/10.1186/1472-6939-12-17

Pettit, T.J., Croxton, K.L. \& Fiksel, J., 2013, ‘Ensuring supply chain resilience development and implementation of an assessment tool', Journal of Business Logistics 34(1), 46-76. https://doi.org/10.1111/jbl.12009

Pfohl, H.-C., Köhler, H. \& Thomas, D., 2010, 'State of the art in supply chain risk management research: Empirical and conceptual findings and a roadmap for the implementation in practice', Logistics Research 2(1), 33-44. https://doi. org/10.1007/s12159-010-0023-8 
Polit, D.F. \& Beck, C.T., 2011, Nursing research: Generating and assessing evidence for nursing practice, 9th edn.,Wolters Kluwer Health/Lippincott Williams \& Wilkins, nursing practice,
Philadelphia, PA

Ponomarov, S.Y. \& Holcomb, M.C., 2009, 'Understanding the concept of supply chain resilience', The International Journal of Logistics Management 20(1), 124-143. https://doi.org/10.1108/09574090910954873

Punniyamoorthy, M., Thamaraiselvan, N. \& Manikandan, L., 2013, 'Assessment of supply chain risk: Scale development and validation', Benchmarking: An InternationalJourna/20(1),79-105. https://doi.org/10.1108/14635771311299506

Rajesh, R., Ravi, V. \& Venkata Rao, R., 2014, 'Selection of risk mitigation strategy in electronic supply chains using grey theory and digraph-matrix approaches', International Journal of Production Research 53(1), 238-257. https://doi.org/10.1 080/00207543.2014.948579

Rotaru, K., Wilkin, C. \& Ceglowski, A., 2014, 'Analysis of SCOR's approach to supply chain risk management', International Journal of Operations \& Production Management 34(10), 1246-1268. https://doi.org/10.1108/IJOPM-09-2012-0385

Sachdeva, A., Kayis, B. \& Dana Karningsih, P., 2012, 'A knowledge-based system tools for assisting manufacturing organisations in identifying supply chain risks', Journa of Manufacturing Technology Management 23(7), 834-852. https://doi. org/10.1108/17410381211267682

Saghafian, S. \& Van Oyen, M.P., 2012, 'The value of flexible backup suppliers and disruption risk information: Newsvendor analysis with recourse', IIE Transaction 44(10), 834-867. https://doi.org/10.1080/0740817X.2012.654846

Sandelowski, M., 2000, 'Focus on research methods - Whatever happened to qualitative description?', Research in Nursing and Health 23(4), 334-340. https:// doi.org/10.1002/1098-240X(200008)23:4<334::AID-NUR9>3.0.CO;2-G

Scannell, T., Curkovic, S. \& Wagner, B., 2013, 'Integration of ISO 31000:2009 and supply chain risk management', American Journal of Industrial and Busines Management 03(4), 367-377. https://doi.org/10.4236/ajibm.2013.34043

Scholten, K., Sharkey Scott, P. \& Fynes, B., 2014, 'Mitigation processes - Antecedents for building supply chain resilience', Supply Chain Management: An International Journal 19(2), 211-228. https://doi.org/10.1108/SCM-06-2013-0191

Sharma, S.K. \& Bhat, A., 2014, 'Supply chain risk assessment tools and techniques in the automobile industry: A survey', The IUP Journal of Supply Chain Management 11(1), 67-78.

Sodhi, M.S., Son, B. \& Tang, C.S., 2012, 'Researchers' perspectives on supply chain risk management', Production and Operations Management 21(1), 1-13. https://doi. org/10.1111/j.1937-5956.2011.01251.x

Soni, G. \& Kodali, R., 2013, 'A decision framework for assessment of risk associated with global supply chain', Journal of Modelling in Management 8(1), 25-53. https://doi.org/10.1108/17465661311311969

Spiegler, V.L.M., Naim, M.M. \& Wikner, J., 2012, 'A control engineering approach to the assessment of supply chain resilience', International Journal of Production Research 50(21), 6162-6187. https://doi.org/10.1080/00207543.2012.710764

The Global Supply Chain Institute, 2014, Managing risk in the global supply chain, pp. 1-36, viewed 22 April 2017, from http://globalsupplychaininstitute.utk.edu/ publications/documents/Risk.pdf
Thun, J.-H., Drüke, M. \& Hoenig, D., 2011, 'Managing uncertainty - An empirical analysis of supply chain risk management in small and medium-sized enterprises', International Journal of Production Research 49(18), 5511-5525. https://doi.org/ 10.1080/00207543.2011.563901

öyli, J., Wieland, A. \& Marcus Wallenburg, C., 2013, 'The influence of relational competencies on supply chain resilience: A relational view', International Journal of Physical Distribution \& Logistics Management 43(4), 300-320. https://doi. org/10.1108/IJPDLM-08-2012-0243

Trkman, P. \& McCormack, K., 2009, 'Supply chain risk in turbulent environments - A conceptual model for managing supply chain network risk', Internationa Journal of Production Economics 119(2), 247-258. https://doi.org/10.1016/j. ijpe.2009.03.002

Urciuoli, L., Mohanty, S., Hintsa, J. \& Gerine Boekesteijn, E., 2014, 'The resilience of energy supply chains: A multiple case study approach on oil and gas supply chains to Europe', Supply Chain Management: An International Journal 19(1), 46-63. https://doi.org/10.1108/SCM-09-2012-0307

Vedel, M. \& Ellegaard, C., 2013, 'Supply risk management functions of sourcing intermediaries: An investigation of the clothing industry', Supply Chain Management: An International Journal 18(5), 509-522. https://doi.org/10.1108/ SCM-09-2012-0295

Vilko, J., Ritala, P. \& Edelmann, J., 2014, 'On uncertainty in supply chain risk management', International Journal of Logistics Management 22(1), 3-19. https://doi.org/10.1108/IJLM-10-2012-0126

Wagner, S.M. \& Neshat, N., 2012, 'A comparison of supply chain vulnerability indices for different categories of firms', International Journal of Production Research 50(11), 2877-2891. https://doi.org/10.1080/00207543.2011.561540

Wieland, A., 2013, 'Selecting the right supply chain based on risks', Journal of Manufacturing Technology Management 24(5), 652-668. https://doi.org/ 10.1108/17410381311327954

Wieland, A. \& Marcus Wallenburg, C., 2012, 'Dealing with supply chain risks: Linking risk management practices and strategies to performance', International Journal of Physical Distribution \& Logistics Management 42(10), 887-905. https://doi. org/10.1108/09600031211281411

Wilding, R., Colicchia, C. \& Strozzi, F., 2012, 'Supply chain risk management: A new methodology for a systematic literature review', Supply Chain Management: An International Journal 17(4), 403-418. https://doi.org/10.1108/13598541211 246558

Xie, C., Tummala, R. \& Schoenherr, T., 2011, 'Assessing and managing risks using the Supply Chain Risk Management Process (SCRMP)', Supply Chain Management: An International Journal 16(6), 474-483. https://doi.org/10.1108/13598541111 171165

Zamora, J.P., Adarme, W. \& Palacios, L., 2012, 'Risk monitoring through traceability information model', World Academy of Science, Engineering and Technology 71 , 396-400.

Zsidisin, G.A. \& Wagner, S.M., 2010, 'Do perceptions become reality? The moderating role of supply chain resiliency on disruption occurrence', Journal of Business Logistics 31(2), 1-20. https://doi.org/10.1002/j.2158-1592.2010.tb00140.x 